\title{
VRAGEN OVER-.
}

\section{Het afschaffen van de directe financiering}

Het kabinet ziet af van de directe financiering in de kinderopvang. In plaats daarvan wordt een verbetertraject gestart met de Belastingdienst. Een nieuwe financiering via DUO betekent een stelselwijziging en dat kan gepaard gaan met te veel risico's, legt staatssecretaris Tamara van Ark de beslissing uit.

Wat vindt BOinK, de belangenvereniging van ouders, van dit besluit?

'Wij zagen in het nieuwe systeem voor Financiering Kinderopvang via DUO goede mogelijkheden om de risico's en problemen rondom kinderopvangtoeslag voor een groot deel terug te dringen. Want ouders komen vaak in groter financiële problemen vanwege problemen met kinderopvangtoeslag. In die zin is dit besluit voor ouders een grote deceptie en zijn we weer terug bij af.'

De twee brancheverenigingen reageren heel verschillend. Wat zeggen zij?

Wout Slob namens de Brancheorganisatie: 'Hoewel het bericht ook voor ons als donderslag bij heldere hemel kwam, denk ik dat bij veel ondernemers de opluchting overheerst. Want er kleefden ook veel risico's aan de directe financiering.'

Sharon Gesthuizen van BMK noemt het besluit te stoppen met de directe financiering verbijsterend. 'De kinderopvangtoeslag is heel vaak een bron van schulden en zware schuldenproblematiek. Uitermate jammer dat een systeem dat die problematiek zou kunnen verminderen nu vroegtijdig ter ziele gaat.'

Verandert er überhaupt iets aan de financiering van kinderopvangtoeslag?

Dat is wel de bedoeling, maar het direct overmaken van kinderopvangtoeslag naar de kinderopvangorganisaties lijkt van de baan. In plaats daarvan moet de huidige werkwijze van de Belastingdienst verbeterd worden. De Belastingdienst heeft hiervoor een verbeterplan gemaakt.

\section{Panelvraag}

GAAT DE MENTALITEIT VAN STAGIAIRES DE LAATSTE JAREN (GEMIDDELD) OMLAAG?

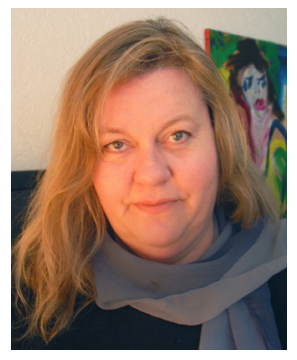

'De passie voor het vak is bij veel stagiaires nog net zo aanwezig als in het verleden. De mentaliteit wordt natuurlijk wel maatschappelijk beinvloed, zoals dat bij iedereen het geval is. Verder zie ik wel een verschil in achtergrondfactoren, waarbij bijvoorbeeld veel stagiaires naast school en stage ook nog werken om rond te komen. De belasting kan daardoor zwaarder zijn dan voorheen en kan die passie beïnvloeden. En niet iedereen is even geschikt voor het competentiegericht onderwijs, daar moeten scholen op maat de leerling begeleiden.'

JACQUELINE BUTTI IS PEDAGOGISCH MEDEWERKER OP EEN BSO-GROEP VAN KOREIN KINDERPLEIN

'Het is de laatste jaren ingewikkelder geworden om stagiaires te vinden die bij ons bedrijf passen. Toch zie ik bij ons gemotiveerde stagiaires. Om bij De Sterren stage te lopen sturen de stagiaires hun motivatie en CV op en aan de hand hiervan vindt er een kennismakingsgesprek plaats. Ik

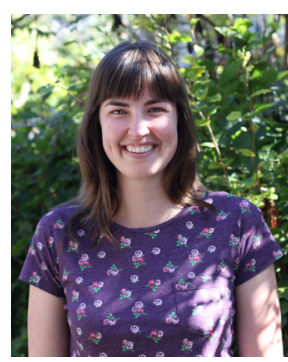
denk dat deze procedure helpt om gemotiveerde stagiaires binnen te halen. Als wij tevreden zijn over een stagiaire en de mogelijk is er, nemen wij iemand graag na de stage in dienst.'

CATHY DE JONG IS PERSONEELSMANAGER BIJ DE STERREN

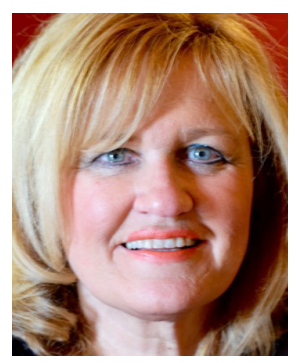

'Ik herken mij in de stelling. Naar mijn idee is gemiddeld genomen de weerbaarheid van kinderen afgenomen en dat zie je tot uitdrukking komen bij stagiaires. Ze weten niet wat ze moeten doen en kijken vaak met de handen in de zij toe, terwijl ze beter de handen uit de mouwen kunnen steken. Dat komt ook omdat het huidige onderwijs nog veel te theoretisch is. Gelukkig zitten er ook goede tussen. Die bieden we steeds vaker een BBL traject aan. Daarnaast werken we in Zuid Limburg nauw samen met roc's vanuit Kinderenonsvak.nl. Een belangrijk doel van deze samenwerking is het afstemmen van het onderwijs op de veranderende behoefte in de kinderopvang.' JOLANDA RIKERS IS DIRECTEUR VAN KINDEROPVANG KERKRADEIPARKSTAD 